\title{
Subchronic oral toxicity study of Vegeta in Sprague-Dawley rats
}

\author{
Hedi R. Dewoto, Frans D. Suyatna
}

\begin{abstract}
Abstrak
Tujuan penelitian ini adalah untuk menentukan keamanan dan efek toksik Vegeta yang diberikan secara oral selama 90 hari pada tikus. Delapan puluh tikus strain Sprague-Dawley dibagi secara acak menjadi 4 kelompok. Tiap kelompok terdiri dari 20 tikus, 10 jantan dan 10 betina. Tiap kelompok masing-masing mendapat Vegeta 0,25 g/kg BB; 0,50 g/kg BB; 1,00 g/kg BB (dilarutkan dalam akuades), dan kelompok kontrol mendapat 5,00 ml/ kg BB akuades secara oral memalui sonde lambung selama 90 hari. Berat badan dan tingkah laku tikus tiap hari dievaluasi. Pada hari ke 90 hewan coba didekapitasi, sampel darah diambil untuk dinilai kadar hemoglobin, lekosit, SGPT, SGOT, kreatinin, dan ureum. Organ dalam juga diambil, ditimbang dan diperiksa secara mikroskopis. Hasil menunjukkan bahwa

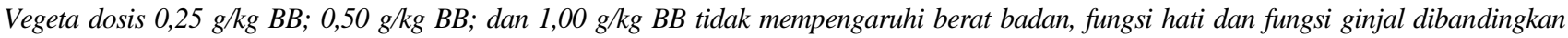
kelompok kontrol. Dibandingkan dengan kelompok kontrol, tidak didapatkan perbedaan bermakna dalam nilai hemoglobin, tetapi hitung lekosit meningkat pada kelompok yang mendapat 1,00 g/kg BB Vegeta, yang kemungkinan disebabkan oleh infeksi. Berat otak dan limpa tikus jantan, dan berat paru dan jantung tikus betina pada kelompok Vegeta berbeda dibandingkan kelompok kontrol. Tetapi karena perbedaan berat tidak dose related dan tidak didapatkan kelainan mikroskopis yang spesifik dibandingkan kelompok kontrol, ini menunjukkan bukan merupakan efek toksik Vegeta. Nilai No observed effect level (NOEL) Vegeta 90 hari pemberian secara oral pada tikus jantan dan betina strain Sprague-Dawley adalah 1,00 g/kg BB. (Med J Indones 2006; 15:223-8)
\end{abstract}

\begin{abstract}
The objective of this study was to determine the safety and toxic effect of Vegeta giving orally for a period of 90 days in rats. Eighty rats of Sprague-Dawley strain were randomly devided into 4 groups. Each group consists of 20 rats, 10 male and 10 female rats. Each group received $0.25 \mathrm{~g} / \mathrm{kgBW} ; 0.50 \mathrm{~g} / \mathrm{kgBW} ; 1.00 \mathrm{~g} / \mathrm{kgBW}$ Vegeta (in aquadest solution) respectively, and the control group received $5 \mathrm{~mL} / \mathrm{kgBW}$ aquadest, given orally by gastric tube for 90 days. The rat's body weight and behavior were daily evaluated. On the $90^{\text {th }}$ day, the rats were decapitated and the blood samples were withdrawn for evaluation of Hemoglobin, leucocyte, SGPT, SGOT, creatinine, and ureum concentration. Visceral organs were also removed, being weighted and were examined microscopically. The results showed that Vegeta with dose of $0.25 \mathrm{~g} / \mathrm{kgBW} ; 0.50 \mathrm{~g} / \mathrm{kgBW}$, and $1.00 \mathrm{~g} / \mathrm{kgBW}$ did not affect body weight, liver and renal function compared to control group. There was no significant difference for hemoglobin value compared to control group, but the number of leucocyte increased in $1.00 \mathrm{~g} / \mathrm{kgBW}$ Vegeta dose group, which was possibly caused by infection. In Vegeta group, there was different spleen and brain weight in male rats, and different lung and heart weight in female rats compared to the control group. However, since it was not dose-related and there was no specific abnormality in microscopic examination compared to the control group, it was not indicated as Vegeta toxic effect. The No observed effect level (NOEL) value of Vegeta for 90 day oral administration in male and female rats of Sprague-Dawley strain was $1.00 \mathrm{~g} / \mathrm{kgBW}$. (Med J Indones 2006; 15:223-8)
\end{abstract}

Keywords: Vegeta, subchronic toxicity, oral, rats

Vegeta is a food supplement containing soluble and insoluble fiber. It appears to be rquired in providing fiber when people consume less natural fiber in the form of vegetables or fruits in our daily meal. Plantago ovata (Psyllium) and Inulin chicory are major soluble and insoluble fibers in Vegeta. Plantago ovata, a

Department of Pharmacology \& Therapeutics, Faculty of Medicine, University of Indonesia, Jakarta, Indonesia component of Vegeta may help diet program in reducing weight since it may sigificantly increase feeling of stomach fullness. ${ }^{1,2}$ Dietary fiber is used for prevention and treatment of constipation. ${ }^{3}$ It may enhance defecation process because of its hygroscopic nature, and acts as a lubricant. ${ }^{4}$ Some studies demonstrated that Vegeta may ameliorate the LDLcholesterol level. Meta analysis of 8 controlled trials found cholesterol-lowering effects of Plantago ovata intake adjunctive to diet therapy in men and women with hypercholesterolemia. ${ }^{5}$ 
This study was aimed to investigate the subchronic toxicity of Vegeta in rats considering it as a food supplement which may be consumed in long-term period.

\section{METHODS}

\section{Material}

Vegeta, a yellow powder packed in sachet form. Vegeta was dissolved in aquadest and the highest Vegeta concentration that could be given to rats through a gastric tube was $1 \mathrm{~g} / 10 \mathrm{~mL} / \mathrm{kgBW}$.

\section{Experimental animals}

Eighty Sprague-Dawley rats from the Directorate General, Drug and Food Regulation (POM), aged range 6-8 weeks, weighed between 110-150 gram were used. These rats were randomly devided into 4 groups. Each group consisted of 20 rats, 10 male and 10 female rats. The $1^{\text {st }}, 2^{\text {nd }}$ and $3^{\text {rd }}$ group received three different concentrations of Vegeta and the $4^{\text {th }}$ group was the control group. During the evaluation, the experimental animals consumed standard rat's food and drank ad libitum.

\section{Administration of Vegeta}

Vegeta solution was given orally by gastric tube in a volume of less than $1 \%$ of body weight, once daily for 90 days. Vegeta was given in 3 dose level. The highest level of dosage was the dosage that was expected to result in toxic effects and fatal death in some experimental animals, while the lowest dosage should not. ${ }^{6}$ Based on the preliminary experiment, it was determined to administer the following dosage :

$$
\begin{array}{ll}
1^{\text {st }} \text { Group } & : 0.25 \mathrm{~g} / \mathrm{kgBW} \text { of Vegeta }\left(D_{1}\right) \\
2^{\text {nd }} \text { Group } & : 0.50 \mathrm{~g} / \mathrm{kgBW} \text { of Vegeta }\left(D_{2}\right) \\
3^{\text {rd }} \text { Group } & : 1.00 \mathrm{~g} / \mathrm{kgBW} \text { of Vegeta }\left(D_{3}\right) \\
4^{\text {th }} \text { Group } & : 5 \mathrm{~mL} / \mathrm{kgBW} \text { of aquadest as control, }(\mathrm{C})
\end{array}
$$

\section{Observation}

1. Body weight was determined daily and evaluated on day 0,30,60, and 90 .

2. Behavior and clinical symptoms were daily observed and recorded

3. At the end of study, the rats were decapitated, the blood sample was withdrawn. Of the blood it was examined $\mathrm{Hb}$, leukocyte, SGPT, SGOT, creatinine and ureum concentration. Visceral organs such as kidney, liver, heart, lung, spleen and brain were removed, cleaned from surrounding tissue, weighted and fixed in $10 \%$ formalin solution. A piece of tissue of each organ was dehydrated in graded concentration of alcohol and embedded in paraffin block according to the routine standard method. Then, it was cut by microtome and stained with hematoxylin eosin for hitological slides.

\section{Statistical Analysis}

Data comparison of all groups was conducted by oneway analysis of variance followed by Fisher test for inter-group comparison, with the limit of significance of 0.05 .

\section{RESULTS}

\section{Body weight}

\section{Male rats}

At the beginning of study and in the $30^{\text {th }}, 60^{\text {th }}$, and $90^{\text {th }}$ day, there was no significance difference of body weight in male rats between 4 groups, which received $0.25 \mathrm{~g} / \mathrm{kgBW}, 0.50 \mathrm{~g} / \mathrm{kg} \mathrm{BW}, 1.00 \mathrm{~g} / \mathrm{kgBW}$ of Vegeta respectively and aquadest (the control group). In

\begin{tabular}{|c|c|c|c|c|}
\hline \multirow{2}{*}{ Day } & \multirow{2}{*}{$\begin{array}{l}\text { Control } \\
\text { (C) }\end{array}$} & \multicolumn{3}{|c|}{ Vegeta } \\
\hline & & $\begin{array}{c}0.25 \mathrm{~g} / \mathrm{kg} \mathrm{BW} \\
\left(\mathrm{D}_{1}\right)\end{array}$ & $\begin{array}{c}0.50 \mathrm{~g} / \mathrm{kgBW} \\
\left(\mathrm{D}_{2}\right)\end{array}$ & $\begin{array}{c}1.00 \mathrm{~g} / \mathrm{kg} \mathrm{BW} \\
\left(\mathrm{D}_{3}\right)\end{array}$ \\
\hline 0 & $128 \pm 13$ & $128 \pm 13$ & $128 \pm 13$ & $128 \pm 13$ \\
\hline 30 & $172 \pm 9$ & $174 \pm 12$ & $176 \pm 11$ & $180 \pm 11$ \\
\hline 60 & $215 \pm 19$ & $226 \pm 13$ & $223 \pm 21$ & $223 \pm 16$ \\
\hline 90 & $254 \pm 25$ & $257 \pm 17$ & $255 \pm 24$ & $259 \pm 23$ \\
\hline
\end{tabular}
general, the body weight of male rats increased similarly in all groups (Table 1).

Table 1 . Body weight of male rats (gram, $X \pm S D$ )

\section{Female rats}

At the beginning of study (Day 0) and the $30^{\text {th }}$ day, there was no significant difference in female body weight within 4 groups, which received $0.25 \mathrm{~g} / \mathrm{kgBW}$, $0.50 \mathrm{~g} / \mathrm{kgBW}, 1.00 \mathrm{~g} / \mathrm{kgBW}$ Vegeta dose, and aquadest (control). On the $60^{\text {th }}$ day, the group which received $0.25 \mathrm{~g} / \mathrm{kgBW}$ and $1.00 \mathrm{~g} / \mathrm{kgBW}$ of Vegeta showed a 
lower body weight compared to the control group, while the body weight in the $0.50 \mathrm{~g} / \mathrm{kgBW}$ dose group and the control group was not significant different. On the $90^{\text {th }}$ day, body weight in group which received Vegeta of $0.25 \mathrm{~g} / \mathrm{kg} \mathrm{BW}$ was lower than the control group, while the body weight in the higher Vegeta dose groups and the control group was not significant different (Table 2).

Table 2. Body weight of female rats (gram, $X \pm S D$ )

\begin{tabular}{ccccc}
\hline \multirow{2}{*}{ Day } & $\begin{array}{c}\text { Control } \\
(\mathrm{C})\end{array}$ & $\begin{array}{c}0.25 \mathrm{~g} / \mathrm{kgBW} \\
\left(\mathrm{D}_{1}\right)\end{array}$ & $\begin{array}{c}0.50 \mathrm{~g} / \mathrm{kgBW} \\
\left(\mathrm{D}_{2}\right)\end{array}$ & $\begin{array}{c}1.00 \mathrm{~g} / \mathrm{kgBW} \\
\left(\mathrm{D}_{3}\right)\end{array}$ \\
\hline 0 & & $127 \pm 14$ & $127 \pm 14$ & $127 \pm 14$ \\
30 & $163 \pm 11$ & $160 \pm 11$ & $162 \pm 12$ & $162 \pm 14$ \\
60 & $205 \pm 12$ & $186 \pm 14^{\mathrm{a}}$ & $193 \pm 20$ & $185 \pm 13^{\mathrm{a}}$ \\
90 & $225 \pm 15$ & $207 \pm 14^{\mathrm{a}}$ & $213 \pm 20$ & $213 \pm 15$ \\
\hline
\end{tabular}

${ }^{\mathrm{a}} \mathrm{p}<0.05$ lower than the control group

\section{Mortality, behavior, and clinical symptom}

During 90 day observation, there were no mortality, behavior changes or clinical symptoms in the groups receiving Vegeta or the control group, either in male or female rats.

\section{Hemopoietic System}

\section{Hemoglobin $(\mathrm{Hb})$}

Mean $\mathrm{Hb}$ values in male rats which received Vegeta in various dosage were not significant different compared with those of control group, although the group which received $0,25 \mathrm{~g} / \mathrm{kg} \mathrm{BW}$ and $0,50 \mathrm{~g} / \mathrm{kg} \mathrm{BW}$ of Vegeta showed a lower mean $\mathrm{Hb}$ values compared to the highest Vegeta dose group. In female rats, the $\mathrm{Hb}$ values between all groups were not different (Table 3 ).

\section{Leucocyte}

The number of leucocyte in group receiving Vegeta of $1.00 \mathrm{~g} / \mathrm{kgBW}$ both in male and female rats was higher than the groups receiving smaller Vegeta dose and the control group.

\section{Blood chemistry}

\section{Male Rats}

There were no difference of SGOT and SGPT mean values between groups receiving Vegeta and the control group. Mean ureum value in group receiving Vegeta of $0.25 \mathrm{~g} / \mathrm{kgBW}$ was higher than the other Vegeta groups with greater dose and the control group. Mean creatinine value of group receiving Vegeta of $1 \mathrm{~g} / \mathrm{kgBW}$ was higher than the group with lower Vegeta dose, but it was not significantly different from the control group (Table 4).

Table 3. Mean hemoglobin and leucocyte values $(X \pm S D)$ of male and female rats after the administration of various doses of Vegeta

\begin{tabular}{llcccc}
\hline \multirow{2}{*}{ Parameters } & Sex & Control & \multicolumn{3}{c}{ Vegeta } \\
\cline { 4 - 6 } & & $(\mathrm{C})$ & $\begin{array}{c}0.25 \mathrm{~g} / \mathrm{kgBW} \\
\left(\mathrm{D}_{1}\right)\end{array}$ & $\begin{array}{c}0.50 \mathrm{~g} / \mathrm{kgBW} \\
\left(\mathrm{D}_{2}\right)\end{array}$ & $\begin{array}{c}1.00 \mathrm{~g} / \mathrm{kgBW} \\
\left(\mathrm{D}_{3}\right)\end{array}$ \\
\hline $\mathrm{Hb}(\mathrm{g} \%)$ & Male & $15.08 \pm 0.97$ & $14.58 \pm 1.23^{\mathrm{a}}$ & $14.78 \pm 1.35^{\mathrm{a}}$ & $15.82 \pm 0.86$ \\
& Female & $15.32 \pm 0.86$ & $15.22 \pm 0.70$ & $15.28 \pm 1.04$ & $15.66 \pm 0.88$ \\
Leucocytes & Male & $14.200 \pm 1.337$ & $12.780 \pm 1.113$ & $13.820 \pm 2.508$ & $34.060 \pm 43.228^{\mathrm{b}}$ \\
$\left(\sum / \mathrm{mm} 3\right)$ & Female & $13.280 \pm 2.051$ & $13.500 \pm 1.831$ & $14.940 \pm 1.909$ & $15.480 \pm 2.417^{\mathrm{c}}$ \\
\hline
\end{tabular}

${ }^{a} \mathrm{p}<0,05$ lower than $\mathrm{D}_{3}$ group

${ }^{\mathrm{b}} \mathrm{p}<0,05$ higher than $\mathrm{D}_{1}, \mathrm{D}_{2}$, and control groups

${ }^{c} \mathrm{p}<0,05$ higher than $D_{1}$ and control groups 
Table 4. The effects of various doses of Vegeta $(X \pm S D)$ on blood chemistry in male rats

\begin{tabular}{|c|c|c|c|c|}
\hline \multirow{2}{*}{ Parameters } & \multirow{2}{*}{$\begin{array}{l}\text { Control } \\
\text { (C) }\end{array}$} & \multicolumn{3}{|c|}{ Vegeta } \\
\hline & & $\begin{array}{c}0.25 \mathrm{~g} / \mathrm{kgBW} \\
\left(\mathrm{D}_{1}\right)\end{array}$ & $\begin{array}{c}0.50 \mathrm{~g} / \mathrm{kg} \mathrm{BW} \\
\left(\mathrm{D}_{2}\right)\end{array}$ & $\begin{array}{c}1.00 \mathrm{~g} / \mathrm{kg} \mathrm{BW} \\
\left(\mathrm{D}_{3}\right)\end{array}$ \\
\hline SGOT (U/L) & $70 \pm 8$ & $79 \pm 10$ & $77 \pm 15$ & $76 \pm 8$ \\
\hline SGPT(U/L) & $53 \pm 9$ & $62 \pm 16$ & $63 \pm 22$ & $58 \pm 9$ \\
\hline Ureum (mg\%) & $34 \pm 5$ & $53 \pm 15^{\mathrm{a}}$ & $26 \pm 6$ & $28 \pm 6$ \\
\hline Creatinine $(\mathrm{mg} \%)$ & $0.43 \pm 0.08$ & $0.35 \pm 0.11$ & $0.33 \pm 0.11$ & $0.49 \pm 0.10^{\mathrm{b}}$ \\
\hline
\end{tabular}

${ }^{\mathrm{a}} \mathrm{p}<0.05$ higher than $\mathrm{D}_{2}, \mathrm{D}_{3}$, and control groups

${ }^{b} \mathrm{p}<0.05$ higher than $\mathrm{D}_{1}$ and $\mathrm{D}_{2}$ groups

\section{Female Rats}

The SGOT, SGPT, and ureum mean values in group receiving Vegeta of $0.50 \mathrm{~g} / \mathrm{kgBW}$ were significantly higher than the other groups, including the control group, but it was not dose-dependent. Mean creatinine values in groups receiving Vegeta were not significantly different compared with that of control group (Table 5).

\section{Organ weight}

\section{Male rats}

Liver, kidney, lung, heart and intestinal weight were not significantly different between groups receiving Vegeta. and that of control group. Spleen weight in rats receiving Vegeta of $1.00 \mathrm{~g} / \mathrm{kg} \mathrm{BW}$ was heavier than those of lower dose of Vegeta and control group. Brain weight of rats receiving Vegeta of $0.25 \mathrm{~g} / \mathrm{kgBW}$ was lower than those of higher doses of Vegeta and control group (Table 6).

Table 5. The effects of various doses of Vegeta $(\mathrm{X} \pm \mathrm{SD})$ on blood chemistry in female rats

\begin{tabular}{ccccc}
\hline & & \multicolumn{3}{c}{ Vegeta } \\
\cline { 3 - 4 } Parameters & $(\mathrm{C})$ & $0.25 \mathrm{~g} / \mathrm{kgBW}$ & $0.50 \mathrm{~g} / \mathrm{kgBW}$ & $1.00 \mathrm{~g} / \mathrm{kgBW}$ \\
& & $\left(\mathrm{D}_{1}\right)$ & $\left(\mathrm{D}_{2}\right)$ & $100 \pm 19$ \\
\hline SGOT (U/L) & $85 \pm 20$ & $68 \pm 14$ & $125 \pm 31^{\mathrm{a}}$ & $77 \pm 18$ \\
SGPT (U/L) & $61 \pm 31$ & $43 \pm 24$ & $100 \pm 42^{\mathrm{b}}$ & $42 \pm 9$ \\
Ureum (mg \%) & $36 \pm 8$ & $0.42 \pm 0.12$ & $62 \pm 14^{\mathrm{a}}$ & $0.46 \pm 0.06$ \\
Creatinine (mg \%) & $0.40 \pm 0.05$ & & $0.37 \pm 0.14$ & 12 \\
\hline
\end{tabular}

${ }^{a} \mathrm{p}<0.05$ higher than $\mathrm{D} 1, \mathrm{D} 3$, and control group

${ }^{\mathrm{b}} \mathrm{p}<0.05$ higher than D1 and control group

Table 6. The organ weight in male rats receiving Vegeta and control group

\begin{tabular}{|c|c|c|c|c|}
\hline \multirow{2}{*}{ Organ } & \multirow{2}{*}{$\begin{array}{l}\text { Control } \\
\text { (C) }\end{array}$} & \multicolumn{3}{|c|}{ Vegeta } \\
\hline & & $\begin{array}{c}0.25 \mathrm{~g} / \mathrm{kgBW} \\
\text { (D1) }\end{array}$ & $\begin{array}{c}0.50 \mathrm{~g} / \mathrm{kgBW} \\
\text { (D2) }\end{array}$ & $\begin{array}{c}1.00 \mathrm{~g} / \mathrm{kgBW} \\
\text { (D3) }\end{array}$ \\
\hline Liver $(\mathrm{g})$ & $2.23 \pm 0.35$ & $2.10 \pm 0.17$ & $2.12 \pm 0.17$ & $2.29 \pm 0.25$ \\
\hline Kidney (g) & $0.54 \pm 0.04$ & $0.56 \pm 0.03$ & $0.57 \pm 0.05$ & $0.57 \pm 0.03$ \\
\hline Lung $(\mathrm{g})$ & $0.66 \pm 0.27$ & $0.56 \pm 0.11$ & $0.63 \pm 0.10$ & $0.57 \pm 0.07$ \\
\hline Spleen (g) & $0.14 \pm 0.03$ & $0.16 \pm 0.01$ & $0.15 \pm 0.09$ & $0.18 \pm 0.02^{\mathrm{a}}$ \\
\hline Heart $(\mathrm{g})$ & $0.26 \pm 0.04$ & $0.28 \pm 0.02$ & $0.28 \pm 0.02$ & $0.29 \pm 0.03$ \\
\hline Brain (g) & $0.67 \pm 0.07$ & $0.54 \pm 0.19^{b}$ & $0.71 \pm 0.06$ & $0.70 \pm 0.05$ \\
\hline Intestine (g) & $5.60 \pm 0.78$ & $5.36 \pm 0.36$ & $5.80 \pm 0.44$ & $5.49 \pm 0.82$ \\
\hline
\end{tabular}

${ }^{\mathrm{a}} \mathrm{p}<0.05$ higher than $\mathrm{D}_{1}, \mathrm{D}_{2}$, and control groups

${ }^{b} \mathrm{p}<0$.lower than $\mathrm{D}_{2}, \mathrm{D}_{3}$, and control groups 


\section{Female rats}

There was no significant difference of liver, kidney, spleen, brain and intestinal weight between groups receiving Vegeta and control group. The lung of groups receiving Vegeta was heavier than that of control group, but there was no significant difference within groups receiving Vegeta. The heart of group receiving Vegeta of $1.00 \mathrm{~g} / \mathrm{kg} \mathrm{BW}$ was slightly lower than those of lower dose of Vegeta and control group (Table 7).

\section{Microscopic examination}

Heart. There was no specific abnormality in Vegeta group and control group. In one slide, there was congestion in Vegeta group with dose of $0.25 \mathrm{~g} / \mathrm{kg}$ BW.

Lungs. Pneumonia peribronchialis was found in control group. Pneumonia alveolaris, congestion and hemorrhage were also found in addition to the pneumonia peribronchialis in Vegeta groups, but the severity of pulmonary changes was not dose-related.

Liver. Microscopically, the common changes were sinusoidal dilatation, hyperplasia of biliary tract and congestion. Those changes occurred both in the Vegeta groups and the control group, and it did not indicate any correlation between the dose of Vegeta and the severity of microscopic changes.
Kidney. The common changes were congestion and hemorrhage, which were found both in Vegeta and control group.

Spleen. In general, there was no specific abnormality in spleen. Hemosiderosis, congestion and focal necrosis were found in several spleen both in the Vegeta group and the control group, and there was no correlation between the dose of Vegeta and the severity of microscopic changes.

Intestine. There was no different microscopic appearance between the Vegeta and the control group.

Brain. There was no specific abnormality in the brain.

\section{DISCUSSION}

In male rats, oral administration of Vegeta for a period of 90 days did not cause different body weight between treated groups and the control group. In female rats, there was a lower body weight in the group receiving Vegeta of $0.25 \mathrm{~g} / \mathrm{kgBW}$ and $1 \mathrm{~g} / \mathrm{kgBW}$ compared to the control group after 60 day administration, and there was also a lower body weight in the group receiving Vegeta of $0.25 \mathrm{~g} / \mathrm{kgBW}$ after 90 day administration. But the lower body weights in those groups apparently were not caused by Vegeta since it was not dose-related.

Table 7. The organ weight of female rats groups receiving Vegeta and the control group

\begin{tabular}{lcccc}
\hline & & \multicolumn{3}{c}{ Vegeta } \\
\cline { 3 - 5 } Organ & $\begin{array}{c}\text { Control } \\
(\mathrm{C})\end{array}$ & $\begin{array}{c}0.25 \mathrm{~g} / \mathrm{kg} \mathrm{BW} \\
\left(\mathrm{D}_{1}\right)\end{array}$ & $\begin{array}{c}0.50 \mathrm{~g} / \mathrm{kg} \mathrm{BW} \\
\left(\mathrm{D}_{2}\right)\end{array}$ & $\begin{array}{c}1.00 \mathrm{~g} / \mathrm{kg} \mathrm{BW} \\
\left(\mathrm{D}_{3}\right)\end{array}$ \\
\hline Liver $(\mathrm{g})$ & $2.43 \pm 0.31$ & $2.43 \pm 0.54$ & $2.31 \pm 0.24$ & $2.29 \pm 0.11$ \\
Kidney $(\mathrm{g})$ & $0.61 \pm 0.06$ & $0.60 \pm 0.06$ & $0.62 \pm 0.06$ & $0.57 \pm 0.04$ \\
Lung $(\mathrm{g})$ & $0.56 \pm 0.07$ & $0.70 \pm 0.12^{\mathrm{a}}$ & $0.67 \pm 0.12^{\mathrm{a}}$ & $0.69 \pm 0.07^{\mathrm{a}}$ \\
Spleen $(\mathrm{g})$ & $0.17 \pm 0.02$ & $0.17 \pm 0.02$ & $0.18 \pm 0.02$ & $0.17 \pm 0.02$ \\
Heart (g) & $0.31 \pm 0.03$ & $0.31 \pm 0.02$ & $0.32 \pm 0.04$ & $0.27 \pm 0.03^{\mathrm{b}}$ \\
Brain (g) & $0.75 \pm 0.04$ & $0.80 \pm 0.07$ & $0.80 \pm 0.07$ & $0.80 \pm 0.05$ \\
Intestine $(\mathrm{g})$ & $6.48 \pm 0.56$ & $6.07 \pm 0.75$ & $5.99 \pm 0.50$ & $5.94 \pm 0.32$ \\
\hline
\end{tabular}

${ }^{a} \mathrm{p}<0.05$ higher than the control group

${ }^{\mathrm{b}} \mathrm{p}<0.05$ lowe than $\mathrm{D}_{1}, \mathrm{D}_{2}$, and control groups 
During 90 day Vegeta administration with the dose of $0.25 \mathrm{~g} / \mathrm{kgBW} ; 0.50 \mathrm{~g} / \mathrm{kgBW}$; and $1.00 \mathrm{~g} / \mathrm{kgBW}$ as well as in the control group, no mortality was found. Increased mean ureum value was noted in low-dose Vegeta group, but at higher dose such an increased value did not occur. In conclusion, the increased mean ureum value did not caused by Vegeta. Slight elevation of SGOT, SGPT, and ureum mean value in middle-dose Vegeta group was found in female rats, but it was not dose dependent. It was concluded that Vegeta administration did not affect liver and renal function both in male and female rats. There was no difference of hemoglobin level between the Vegeta and the control group both in male and in female rats. Greater number of leucocytes was found both in male and female rats receiving Vegeta of $1.00 \mathrm{~g} / \mathrm{kgBW}$ compared with other Vegeta groups and the control group. It might be caused by infection. In male rats there was slight elevation of spleen weight in group with high Vegeta dose $(1.00 \mathrm{~g} / \mathrm{kgBW})$, and the brain weight in group with low Vegeta dose is lower than the control group. Apparently it was not caused by Vegeta, since there was no specific abnormality microscopically and or it did not have any dose-dependent characteristic. In female rats, lung weight in Vegeta groups were higher than the control group, and the heart weight in highdose Vegeta group was lower than the other groups. However, since it was not dose-dependent and there was no specific abnormality, it seems that the changes of such organ weight were not caused by Vegeta. Pneumonia peribronchialis was found microscopically both in the Vegeta groups and the control group; The lung changes are assumed to be occurred naturally because the Sprague-Dawley strain is sensitive to lung infection. Liver did not show serious abnormality microscopically, and mild liver abnormality was found both in the Vegeta group and the control group.

\section{CONCLUSIONS}

Oral Vegeta administration with the dose of 0.25 $\mathrm{g} / \mathrm{kgBW} ; 0.50 \mathrm{~g} / \mathrm{kgBW}$; and $1.00 \mathrm{~g} / \mathrm{kgBW}$ for 90 days did not affect the body weight, although slight differences which were not dose related were found in female rats. No mortality was found both in the Vegeta and the control group. Vegeta did not affect hemoglobin value.The high leucocytes number in the Vegeta group with $1.00 \mathrm{~g} / \mathrm{kgBW}$ dose might be caused by infection. Renal and liver function was not altered by Vegeta, although slight differences which were not dose related were found. In Vegeta group, slight changes of spleen and brain weight in male rats as well as lung and heart weight in female rats apparently were not caused by Vegeta toxic effect, because the weight changes were not dose-related and there were no specific disorders. Microscopic examination indicated that Vegeta did not cause any changes due its toxic effect in visceral organs.

The No Observed Effect Level (NOEL) value of Vegeta for 90 day oral administration in male and female rats of Sprague-Dawley strain was $1.00 \mathrm{~g} / \mathrm{kgBW}$.

\section{REFERENCES}

1. Turnbull WH, Thomas HG. The effect of Plantago ovata seed containing preparation on appetite variables, nutrient, and energy intake. Int $\mathbf{J}$ Obes Relat Metab Disord 1995;19:338-42.

2. Marteau P, Flourie B, Cherbut C,et al. Digestibility and bulking effect of Ispaghula husks in healthy humans. Gut 1994;35:1747-5

3. Voderholzer WA, Schatke W, Muhldorfer BE, et al. Clinical response to dietary fiber treatment of chronic constipation. Am J Gastroenterol 1997;92:95-8.

4. Marlett JA, Kajs TM, Fischer MH. An unfermented gel component of psyllium seed husk promotes laxation as a lubricant in humans. Am J Clin Nutr 2000;72:784-9.

5. Anderson JW,Allgood LD, Lawrence A, et al.Cholesterol -lowering effects of psyllium intake adjunctive to diet therapy in men and women with hypercholesterolemia: meta-analysis of 8 controlled trials. Am J Clin Nutr 2000;71:472-9.

6. Hodgson E. Toxicity testing and risk assesment. In : Hudgson E, Levi PE, editors. Text book of Modern Toxicology. $2^{\text {nd }}$ ed. Connecticut : Apple \& Lange. 1997. p.298-303. 